\title{
Kontribusi Identitas Etnis dan Identitas Akademik terhadap Subjective Well-Being Mahasiswa
}

\author{
Zakki Nurul Amin ${ }^{1}$, JT. Lobby Loekmono², Afriyadi Sofyan', Vira Mulyawati'. \\ ${ }^{1}$ Universitas Negeri Semarang, Indonesia. \\ ${ }^{2}$ Universitas Kristen Satya Wacana, Indonesia. \\ *Korespondensi: zakki.nurul.amin@mail.unnes.ac.id
}

\begin{abstract}
College is an accumulation of social-academic components that interact with each other and are pluralistic. Positive interaction between social and academic components can support individual wellbeing. This study focuses on the psychological construct (subjective well-being) of Javanese college students on two main sources of students, the social component (ethnic identity) and the academic component (academic identity). Partially, the results of this study indicate that only academic identity has a significant relationship with subjective well-being $(r=0.33, p<0.01)$. While using multiple linear regression analysis shows the results that ethnic identity and academic identity have a significant contribution to subjective well-being $(F=8.83, p<0.01)$. This finding has implications for primary student services to improve student subjective well-being.
\end{abstract}

Keywords: Ethnic Identity; Academic Identity; Subjective Well-Being

\begin{abstract}
Abstrak
Perguruan tinggi merupakan akumulasi komponen sosial-akademik yang saling berinteraksi dan bersifat majemuk. Interaksi posiftif antar keduanya yang terjalin secara dinamis dan harmonis dapat menunjang well-being individu. Penelitian ini memfokuskan pada konstruk psikis (subjective well-being) mahasiswa keturunan Jawa pada dua sumber utama pada mahasiswa, yakni komponen sosial (identitas etnis) dan komponen akademik (identitas akademik). Secara parsial, hasil penelitian ini menunjukkan bahwa hanya identitas akademik yang mempunyai hubungan signifikan dengan subjective well-being $(r=0,33, p<0,01)$. Sedangkan menggunakan analisis regresi linear ganda menunjukkan hasil bahwa identitas etnis dan identitas akademik mempunyai kontribusi yang signifikan terhadap subjective well-being $(F=8.83, p<0.01)$. Temuan ini memberikan implikasi bagi pelayanan kemahasiswaan utamaya untuk meningkatkan subjective well-being mahasiswa.
\end{abstract}

Kata Kunci: Identitas Etnis; Identitas Akademik; Kesejahteraan Psikologis

How To Cite: Amin, Z. N. A., Loekmono, JT. L., Sofyan, A., \& Mulyawati, V. (2020). Kontribusi Identitas Etnis dan Identitas Akademik terhadap Subjective Well-Being Mahasiswa. Biblio Couns: Jurnal Kajian Konseling dan Pendidikan, 3(2), 67-73.

\section{PENDAHULUAN}

Sebagai salah satu faktor yang mempengaruhi hasil dan perkembangan pembelajaran, well-being memiliki peran penting bagi mahasiswa (Frost, 2010). Well-being adalah kemampuan siswa untuk menyelaraskan tuntutan dari diri mereka sendiri dan lingkungan yang ditandai dengan pengaruh positif. Well-being juga digambarkan sebagai kepuasan 
mahasiswa dengan diri mereka sendiri dan lingkungan mereka, yang dapat membantu mahasiswa untuk memainkan peran aktif di jalur akademik (Wikanestri \& Prabowo, 2015).

Sebagai bagian dari ranah psikologi positif, Weisner dalam Bornstein, Davidson, Keyes \& Moore (2003) menyatakan well-being sebagai pencapaian keberhasilan hidup yang ditandai oleh integrasi fungsi fisik, kognitif dan fungsi sosial-emosional. Integrasi semua aspek memungkinkan seseorang untuk memiliki peran komunitas, memenuhi kebutuhan hubungan sosial, dan mampu mengatasi masalah psikososial dan lingkungan.

Berkaitan dengan well-being mahasiswa, perguruan tinggi sebagai sistem sosial akademik merupakan akumulasi komponen akademik dan kelompok sosial yang saling berinteraksi dan bersifat majemuk. Mahasiswa berinteraksi dengan berbagai kelompok yang ada di perguruan tingi, mereka juga hidup sebagai bagian dari suatu kelompok, belajar dalam kelompok, berinteraksi dengan teman sebaya dalam kelompok dan menghabiskan sebagian besar waktu luang dalam kelompok (Johnson \& Johnson, 1997). Interaksi sosial positif di perguruan tinggi merupakan hubungan yang terjalin secara dinamis, harmonis, dan dapat menunjang well-being individu (Amin, Wibowo, Nusantoro, 2014).

Komponen sosial yang akan dikaji pada penelitian ini adalah identitas etnis yang dipahami sebagai suatu rasa kebersamaan untuk memiliki dan menjadi bagian dari kelompok etnis (Phinney, 1992). Ketika mahasiswa dalam kelompoknya mempunyai identitas etnis yang tinggi akan menciptakan rasa afiliasi yang dapat memberikan perlindungan terhadap efek dari prasangka terkait dengan ras dan stres yang berhubungan dengan ras dalam kaitannya dengan well-being. Identitas etnis mempunyai korelasi yang positif untuk membantu individu mencapai well-being, bahkan secara khusus salah satu fungsi dari identitas etnis adalah untuk memperkuat individu terhadap efek negatif dari stres dan kecemasan (Phinney, Horenczyk, \& Vedder, 2001; Oliveira \& Cabecinhas, 2012).

Pada penelitian ini secara khusus mengambil subyek mahasiswa keturunan Jawa. Martaniah (dalam Amin, Wibowo, Loekmono, Hariyadi, Isrofin, 2017) menjelaskan bahwa suku Jawa adalah kelompok etnis di Indonesia yang asalnya hidup di Jawa bagian tengah dan timur. Daerah tersebut yang dianggap sebagai pusat kebudayaan Jawa yang bersumber pada kerajaan-kerajaan yang ketika masa lampau disebut dengan "kraton".

Sedangkan mahasiswa keturunan Jawa, pada tulisan ini dipahami sebagai mahasiswa yang mempunyai garis keturunan berasal dari keluarga Jawa dan mempunyai karaktersitik khusus budaya Jawa. Dalam konteks budaya Jawa, siswa keturunan Jawa dipandang bukan sebagai persekutuan individu-individu, melainkan suatu kesatuan kelompok dan sebagai keluarga (Herusasoto, 2001).

Pada mumnya masyarakat jawa merupakan salah satu etnis yang menjunjung tinggi serta memiliki kesetiaan terhadap nilai budaya yang dimilikinya (Amin, Wibowo, Loekmono, Hariyadi, Isrofin, 2017). Salah satu budaya yang masih dijunjung tinggi yakni budaya kolektivitas/kebersamaan. Perasaan ini turut menjadikan mahasiswa keturunan Jawa semakin tinggi identitas etnisnya selain memang berada pada posisi kelompok mayoritas. Budaya dan pandangan hidup yang mengutamakan kebersamaan dan perasaan saling memiliki menjadi kekuatan utamam munculnya identitas etnis pada suatu kelompok (Phinney, 1992).

Sedangkan komponen akademik pada penelitian ini menkaji tentang identitas akademik. Walker dan Syed (2013) mengoperasionalkan identitas akademik sebagai koneksi subjektif pada jurusan akademik yang menjadi pilihan dan kegiatan akademik mahasiswa. Konsepsi itu dikembangkan karena jurusan akademik siswa berfungsi sebagai mikrokonteks dalam konteks perguruan tinggi yang lebih besar, dan menentukan dengan siapa para siswa menghabiskan waktu kelas mereka dan bagian-bagian kampus yang mereka tempati. 
Hasil dari penelitian ini diharapkan mampu memberikan temuan kaitannya dengan kontribusi identitas etnis dan identitas akademik terhadap subejctive well-being pada mahasiswa. Informasi yang diperolah akan dapat memberikan implikasi bagi lembaga fakultas ilmu pendidikan sebagai upaya peningkatan kesejahteraan dan kebahagian mahasiswa.

\section{METODE}

\section{Prosedur dan Subyek Penelitian}

Desain penelitian yang digunakan dalam penelitian ini adalah desain penelitian korelasional. Subyek dalam penelitian ini berjumlah 176 orang mahasiswa Fakultas IImu Pendidikan Unnes yang diambil berdasarkan random sampling. Namun kaitan dengan etnis responden yang beragam, pada analisis data responden yang digunakan berjumlah 145 orang mahasiswa Fakultas IImu Pendidikan yang beretnis Jawa, sedangkan 36 orang responden yang beretnis selain Jawa tidak disertakan pada analisis data penelitian. Pengambilan data dilakukan secara langsung diisi oleh responden yang bersedia mengisi data.

\section{Alat Pengumpul Data}

Multigroup Ethnic Identity Measure Revised (MEIM-R), dikembangkan oleh Phinney \& Ong (2007) untuk mengukur identitas etnis seseorang yang terdiri dari 6 item. Ethnic identity dianalisis untuk menunjukkan aspek ethnic exploration dan ethnic commitment. Contoh item dalam instrumen ini yakni "Saya meluangkan waktu untuk mencoba mengetahui lebih lanjut tentang kelompok etnis saya sendiri, seperti sejarah, tradisi, dan adat istiadat". Validitas instrumen menggunakan product moment rentang skor $r$ (0.575 sampai dengan 0.785 ), dan reliabilitas instrumen menggunakan perhitungan Cronbanch's Alpha memperoleh hasil $r=$ 0.818 .

Self-efficacy for learning and performance, dikembangkan oleh Pintrich dkk (1991) terdiri dari 8 item untuk mengukur level keyakinan diri dalam menjalani kegiatan akademik/pelajaran, yang pada penelitian ini kami gambarkan sebagai identitas akademik mahasiswa. Contoh item dalam instrumen ini yakni "Dengan mempertimbangkan kesulitankesulitan yang ada pada perkuliahan, dan keterampilan yang saya miliki, saya pikir saya bisa melakukan yang terbaik dalam proses pembelajaran/kegiatan akademik". Validitas instrumen menggunakan product moment skor $r$ dengan rentang (0.551 sampai dengan 0.751 ), dan reliabilitas instrumen menggunakan perhitungan Cronbanch's Alpha memperoleh hasil $r=$ 0.772 .

Satisfaction with Life Scale (SWLS) dikembangkan oleh Diener, Emmnos, Larsen, \& Griffin (1985) untuk mengukur well-being. Contoh item pada instrumen ini yakni "Dalam kebanyakan hal, hidup saya sudah dekat dengan kondisi ideal saya". Validitas instrumen menggunakan product moment skor $r$ dengan rentang (0.688 sampai dengan 0.753 ), dan reliabilitas instrumen menggunakan perhitungan Cronbanch's Alpha memperolah hasil $r=$ 0.764 .

Penelitian saat ini menggunakan prosedur back translation sebelum proses pengambilan data. Untuk memvalidasi versi Indonesian, instrumen diterjemahkan dari bahasa Inggris ke bahasa Indonesia. Item yang diterjemahkan, terjemahan ulang item ke dalam bahasa Inggris dan perbandingan terjemahan belakang dan kuesioner asli untuk menginformasikan versi akhir dalam bahasa Indonesia. 


\section{Analisis Data}

Analisis regresi linear berganda digunakan untuk menjawab permasalahan penelitian dan mengetahui hubungan antara kedua variabel independen terhadap variabel dependen. Pengolahan data dalam penelitian ini akan dilakukan dengan menggunakan bantuan program SPSS 21.00 for Windows. Analisis regresi linear berganda termasuk dalam kategori statistik parametric. Sebagai syarat statistika parametric, maka untuk dapat menggunakan rumus regesi harus terlebih dahulu perlu dilakukan uji asumsi klasik meliputi normalitas, heterokedastisitas dan random sampling.

\section{HASIL DAN PEMBAHASAN}

Skor rata-rata, standar deviasi, dan zero-order correlations pada setiap variabel ditampilkan pada tabel 1. Antar variabel tidak semuanya mempunyai hubungan langsung yang signifikan. Identitas akademik berkorelasi secara signifikan dengan identitas etnis $(r=0,22, p<0,01)$ dan juga subjective well-being $(r=0,33, p<0,01)$. Sedangkan identitas etnis tidak terbukti berkorelasi dengan subjective well-being $(r=0,07 ; p>0,05)$. Berdasarkan hasil tersebut maka hipotesis pertama yang mengatakan bahwa ada hubungan yang signifikan antara identitas etnis dengan subjective well-being maka tidak terbukti. Sedangkan hipotesis kedua yang mengatakan bahwa ada hubungan yang signifikan antara identitas akademik dengan subjective well-being terbukti signifikan, begitu pula dengan hipotesis ketiga yang juga terbukti bahwa terdapat hubungan yang signifikan antara identitas etnis dengan identitas akademik.

\begin{tabular}{lccccc}
\multicolumn{7}{l}{ Tabel 1 Hasil Preeliminari Korelasi Hubungan Langsung antar Variabel } & & \\
\hline Variabel & $\boldsymbol{M}$ & SD & $\mathbf{1}$ & $\mathbf{2}$ & $\mathbf{3}$ \\
\hline 1. Identitias Etnis & 18,25 & 3,13 & - & & \\
2. Identitas Akademik & 23,93 & 2,87 & $0,22^{* *}$ & - & \\
3. Subjective well-being & 22,57 & 4,54 & 0,07 & $0,33^{* *}$ & - \\
\hline
\end{tabular}

Keterangan: $\mathrm{N}=145$.

* signifikansi $p<0.05$ ** signifikansi $p<0.01$

Tabel 2 Hasil Regresi Linear antar Variabel

\begin{tabular}{cccccc} 
No. & Predictor & Outcome & $\beta$ & $\mathrm{t}$ & Sig. \\
\hline 1 & Identitas Etnis & \multirow{2}{*}{ Subjective well-being } & $-0,00$ & $-0,3$ & 0,97 \\
2 & Identitas Akademik & & 0,53 & 4,11 & $0,00^{\star *}$ \\
\hline
\end{tabular}

Keterangan: $\mathrm{N}=145$.

* signifikansi $p<0.05$ ** signifikansi $p<0.01$. IE $=$ identitas etnis; $I A=i d e n t i t a s$ akademik; $P W B=$ subjective well-being

Selanjutnya untuk menguji hipotesis keempat yakni apakah identitas etnis bersamasama identitas akademik mempunyai kontribusi dengan subjective well-being maka diukur dengan ANOVA menunjukkan bahwa hipotesis terbukti signifikan dengan nilai $F=8,83$, $p<0,01$ seperti yang ditunjukkan pada tabel ANOVA Regresi Ganda berikut.

Tabel 3 Hasil ANOVA Regresi Ganda

\begin{tabular}{|c|c|c|c|c|c|c|}
\hline & Predictor & Outcome & df & Mean $^{2}$ & F & Sig. \\
\hline \multirow{2}{*}{1} & Identitas Etnis - Identitas Akademik & Subjective well-being & 142 & 164,116 & 8,837 &, 000 \\
& & & 144 & 18,572 & & \\
\hline
\end{tabular}


Identitas etnis bersama-sama dengan identitas akademik mempunyai kontribusi pada subjective well-being mahasiswa Fakultas IImu Pendidikan dapat dijelaskan dari kerangka perkembangan identitas etnis dan identitas akademik sebagai bagian dari diri/self, dijelasan pula oleh teori Erikson (dalam Phinney, 1992) mengenai pembentukan identitas ego. Menurut Erikson (dalam Phinney, 1992), identitas dicapai adalah hasil dari periode eksplorasi dan eksperimen yang biasanya terjadi selama masa remaja dan yang mengarah pada keputusan atau komitmen di berbagai segmen kehidupan, seperti pekerjaan, agama, dan orientasi politik.

Perkembangan identitas ego seseorang terjadi pada interakasi seseorang dengan orang lain pada konteks sosial. Mengingat konteks sosial berkaitan pula dengan ras dan etnis, sehingga identitas etnis menjadi domain yang sangat menonjol dari keseluruhan identitas ego (Phinney, 1992). Pendapat itu disampaikan pula oleh Erikson dan Super (dalam Mejia, 2011) juga mengemukakan bahwa setiap orang mengembangkan identitas ego pada dirinya, sedangkan identias etnis merupakan bagian penting dari keseluruhan identitas ego berkaitan pula dengan kesejahteraan hidup seseorang.

Identitas etnis yang dipahami sebagai suatu rasa kebersamaan untuk memiliki dan menjadi bagian dari kelompok etnis (Amin, Wibowo, Loekmono, Hariyadi, Isrofin 2017), mempunyai korelasi yang positif untuk membantu individu mencapai subjective well-being. Ketika mahasiswa dalam kelompoknya mempunyai identitas etnis dan identitas akademik yang tinggi akan menciptakan rasa afiliasi yang dapat memberikan perlindungan terhadap efek dari prasangka terkait dengan ras dan stres yang berhubungan dengan ras dalam kaitannya dengan well-being/kesejahteraan. Perspektif psikologis dan perkembangan sosial menunjukkan bahwa identitas etnis dan akademik yang kuat memunculkan perasaan aman serta memberikan kontribusi positif pada subjective well-being.

Identitas etnis yang dipahami sebagai suatu rasa kebersamaan untuk memiliki dan menjadi bagian dari kelompok etnis, mempunyai korelasi yang positif untuk membantu individu mencapai subjective well-being (Phinney, 1992; Phinney, Horenczyk, \& Vedder, 2001; Oliveira \& Cabecinhas, 2012). Ketika mahasiswa dalam kelompoknya mempunyai identitas etnis dan identitas akademik yang tinggi akan menciptakan rasa afiliasi yang dapat memberikan perlindungan terhadap efek dari prasangka terkait dengan ras dan stres yang berhubungan dengan ras dalam kaitannya dengan well-being/kesejahteraan. Perspektif psikologis dan perkembangan sosial menunjukkan bahwa identitas etnis dan akademik yang kuat memunculkan perasaan aman serta memberikan kontribusi positif pada subjective wellbeing (Phinney, Horenczyk, \& Vedder, 2001; Cross, Pharam \& Helms dalam Oliveira \& Cabecinhas, 2012).

Sedangkan identitas akademik Walker dan Syed (2013) sebagai koneksi subjektif pada jurusan akademik yang menjadi pilihan dan kegiatan akademik mahasiswa. Konsepsi itu dikembangkan karena jurusan akademik siswa berfungsi sebagai mikrokonteks dalam konteks perguruan tinggi yang lebih besar, dan menentukan dengan siapa para siswa menghabiskan waktu kelas mereka dan bagian-bagian kampus yang mereka tempati. Kedua, hanya ada sedikit penelitian tentang aspek psikologis jurusan siswa, dengan sebagian besar penelitian berfokus pada proses pengambilan keputusan. Selanjutnya yang ketiga, jurusan akademik siswa memiliki implikasi untuk karir masa depan mereka setelah mereka meninggalkan perguruan tinggi, dan dengan demikian berfungsi sebagai titik kontinuitas antara perguruan tinggi dan identitas pasca-perguruan tinggi.

Hasil penelitian ini memberikan perhatian pada konstruk budaya dan konstruk sosial akademik yakni identitas etnis dan identitas akademik mempunyai kaitan dengan konstruk psikologis, psychogical well being mahasiswa. Identitas etnis (seperti identitas ras dan akulturasi) menunjukkan bahwa faktor budaya mempengaruhi psychogical well being dan 
sangat dimungkinkan akan terdapat perberbedaan di antara anggota kelompok etnis yang berbeda.

Secara khusus, penelitian ini juga menggarisbawahi peran positif identifikasi etnis sebagai aspek potensial yang dapat mendukung maupun menghambat (Lent, dalam Gushue, 2006) subjektive well-being mahasiswa. Sejauh identitas etnis dan identitas akademik mendukung keyakinan dan efikasi diri individu, penting untuk dipahami bahwa identitas etnis dapat mempengaruhi cara orang untuk merasakan dan merespon hambatan serta berpengaruh pada subjektive well-being mahasiswa.

\section{KESIMPULAN}

Temuan penelitian ini memberikan implikasi untuk memahami pengaruh konteks lingkungan (budaya, identitas etnis, identitas akademik) pada subjective well-being mahasiswa, serta dampaknya pada sikap mahasiswa. Hal itu karena perubahan demografi, latar belakang rasial etnis, dan pengaruh budaya keluarga yang ada Indonesia turut memberikan kontribusi pada kesejahteraan hidup seseorang. Sehingga untuk memahami secara akurat mengenai masalah yang berkaitan dengan kesejahteraan hidup individu, perlu dikaji dari latar belakang budaya dan etnis yang berbeda, konselor perlu memperhatikan aspek personal siswa serta konteks lingkungan budaya.

\section{REFERENSI}

Amin, Z. N., Wibowo, M. E., Loekmono, L., Hariyadi, S., \& Isrofin, B. (2017). Ethnic Identity and Other-group Orientation on Javanese and Chinese Students. Proceeding. International Conference on Teacher Training and Education 2017, Solo, Indonesia.

Amin, Z.N, Wibowo, M.E., \& Nusantoro, E. (2014). Perbandingan orientasi karier siswa keturunan Jawa dengan siswa keturunan Tionghoa. Indonesian Jornal of Guidance and Counseling, 3(3), 8-16.

Bornstein, Davidson, Keyes \& Moore. (2003). Well Being Positive Development. Across The Life Course. London : Lawrence Erlbaum Assoiates

Diener, E., Emmons, R. A., Larsen, R. J., \& Griffin, S. (1985). The Satisfaction with Life. Scale. Journal of Personality Assessment, 49, 71-75

Frost, P. (2010). The Effectiveness of student wellbeing program and service. Melbourne: Victorian Auditor-General's Report

Gushue, G. V. 2006. The relationship of ethnic identity, career decision-making self-efficacy and outcome expectations among Latino/a high school students. Journal of Vocational Behavior, 68(1), 85-95.

Herusasoto, B. (2001). Simbolisme Manusia Dalam Budaya Jawa. Yogyakarta: Hanindita Graha Widya.

Johnson, D.W; Johnson, F.P. (1999). Joining together: group theory and group skills. Boston: Allyn and Bacon.

Mejia, Brenda Xiomara. (2011). Perceived Career Barriers: The Role of Ethnic Identity, Acculturation, and Self-Efficacy Mediators among Latina/o College Students. Disertasi: Columbia University. 
Oliveira, D. R. De, \& Cabecinhas, R. 2012. Ethnic Identity as predictor for the well-being: An exploratory transcultural study in Brazil and Europe Identidad étnica como predictor del bienestar : Estudio exploratorio transcultural en Brasil y Europa, 9, 33-42.

Phinney, J. S. 1992. The Multigroup Ethnic Identity Measure: A New Scale for Use with Diverse Groups. Journal of Adolescent Research, 7, 156-176.

Phinney, J. S., \& Ong, a. D. 2007. Conceptualization and Measurement of Ethnic Identity: Current Status and Future Directions. Journal of Counseling Psychology, 54, 371-281.

Phinney, J. S., Horenczyk, G., \& Vedder, P. 2001. Ethnic Identity , Immigration , and WellBeing: An Interactional Perspective, 57(3), 493-510

Pintrich, P., Smith, D., Garcia, T., \& McKeachie, W.J. 1991.. A manual of the use of the motivated strategies for learning questionnaire (MSLQ). Ann Arbor: The University of Michigan

Walker, L.H.M, Syed, M. 2013. Integrating identities: Ethnic and academic identities among diverse college students. Teachers College Record, 2013.

Wikanestri, W., \& Prabowo, A. (2015). Subjective well-being pada pelaku wirausaha. Psychology Forum UMM, 978-979-796-324-8. 